\title{
PROPERTI SUBJEK BAHASA TETUM DIALEK FOHO DI DESA NANAET DUBESSI, KABUPATEN BELU, PROVINSI NTT
}

\author{
SUBJECT PROPERTY OF TETUM LANGAUGE, FOHO DIALECT IN \\ NANAET DUBESSI VILLAGE, BELU REGENCY, NTT PROVINCE
}

\author{
Buha Aritonang \\ Badan Pengembangan dan Pembinaan Bahasa \\ Jalan Daksinapati Barat IV, Rawamangun, Jakarta, Indonesia 13220 \\ Telepon (021) 4896558, Faksimile 4750407 \\ Pos-el: buhaaritonang@yahoo.co.id
}

\begin{abstract}
Abstrak
Perilaku gramatikal bahasa yang beragam dan tipologi bahasa yang berbeda dari satu bahasa dengan bahasa lain menyebabkan pengertian dan penetapan tentang subjek memunculkan fenomena yang terus dapat diperdebatkan. Sehubungan dengan itu, subjek sebagai salah satu relasi gramatikal dalam bahasa masih memerlukan perhatian para linguis. Tujuan penelitian ini adalah untuk mendeskripsikan properti subjek bahasa Tetum dialek Foho di Desa Nanaet Dubessi, Kabupaten Belu, Provinsi Nusa Tenggara Timur. Properti subjek bahasa itu dideskripsikan dengan pengetesan argumen yang ditengarai sebagai subjek. Metode penelitian menggunakan metode agih (metode distribusional). Hasil penelitian menunjukkan bahwa bahasa Tetum dialek Foho memiliki properti subjek (1) muncul struktur kanonis pada posisi praverbal, (2) dapat disisipkan adverbia dan penegasi di antara subjek sebagai argumen praverbal dengan predikat, (3) dapat direlatifkan subjek (perelatifan subjek), (4) dapat disisipkan penjangka kambang di antara subjek dan predikat, (5) dapat direfleksifkan subjek (perefleksian), (6) dapat dinaikkan objek langsung dan objek tak langsung (argumen yang bukan subjek) menjadi subjek melalui mekanisme penaikan (raising), dan (7) dapat memfokuskan subjek dengan kehadiran pemarkah fokus ne 'yang'.
\end{abstract}

Kata kunci: argumen, praverbal, properti, subjek

\begin{abstract}
The behavior of language grammar which is variety and language typology which is different from one to others caused subject determination and definition as continually debatable. The subject as one of grammatical relation still needs to have attention by linguist. The purpose of this study describes the subject properties of Tetum language, Foho dialect in Nanaet Dubessi Village, Belu Regency, East Nusa Tenggara Province. It is described by using argument testing predicted as subejct. The method is distributional method. The results show that the Tetum language, Foho dialect has the subject property that (1) appears canonical structure in the praverbal position, (2) can be inserted adverb and negation between the subject and predicate, (3) can be become a relative subject, (4) can be inserted between the subject and predicate, (5) can be reflected, (6) can be risen from direct and indirect object to subject through raising mechanism, (7) can focus the subject with the existence of 'ne' focus affixes 'yang'.
\end{abstract}

Keywords: argument, praverbal, properties, subject

\section{Pendahuluan}

Bahasa merupakan fenomena alam yang sangat misteri dan kekhasan. Di samping mempunyai sistem ketatabahasaan, bahasa manusia sarat dengan berbagai muatan psikologis, sosiologis, dan budaya masyarakat penuturnya. Mempelajari bahasa berarti 
belajar tentang manusia sebagai makhluk yang mempunyai derajat kecerdasan tinggi apabila dibandingkan dengan ciptaan Tuhan yang lain (Jufrizal, dkk., 2006: 1).

Bahasa Tetum sebagai salah satu bahasa daerah di Provinsi Nusa Tenggara Timur tentu mempunyai kekhasan seperti bahasa daerah lainnya yang tersebar di penjuru nusantara. Kekhasasan dimaksud adalah adanya variasi dialektal sehingga bahasa itu dibedakan menjadi dua dialek, yaitu dialek Foho dan Fehan. Dialek Foho dituturkan oleh masyarakat asli Kabupaten Belu di Kecamatan Tasifeto Barat dan Tasifeto Barat. Selain kedua kecamatan tersebut, masyarakat asli Kecamatan Biboki Utara, Kabupaten Timor Tengah Utara juga menuturkan dialek Foho. Dialek Fehan dituturkan oleh masyarakat asli Kecamatan Malaka Barat dan Malaka Tengah, Kabupaten Belu (Troebus, dkk., 1987: 10).

Selain pengelompokan dialek tersebut, bahasa itu tentu bertalian juga dengan perilaku gramatikal kebahasaan khususnya relasi gramatikal yang mendukung konstruksi klausa atau kalimat. Menurut Comrie (1983: 59) dan Blake (1981: 1) dalam Budiarta (2013: 246), bahasan relasi gramatikal adalah bagianbagian atau unsur-unsur klausa/kalimat yang dikategorikan sebagai subjek, objek langsung, dan objek tak langsung. Ketiga relasi gramatikal tersebut bersifat sintaktis. Subjek adalah fungsi tertinggi dalam struktur fungsi gramatikal yang bersifat obligatoris (Arka, 1998) dalam Budiarta (2013: 248). Sementara itu, properti subjek secara lintas bahasa bervariasi antara satu bahasa dan bahasa lain. Meskipun demikian, terdapat kesamaan properti subjek, misalnya argumen verba transitif yang berperilaku sama dengan argumen intransitif. Subjek merupakan relasi gramatikal sehingga penentuan subjek itu sendiri hendaknya didasarkan pada perilaku gramatikal.

Dalrymple (2001: 17-19) dalam Budiarta (2013: 250) mengungkapkan bahwa terdapat beberapa alat uji untuk menentukan subjek atau kesubjekan, seperti persesuaian (agreement), hono-rifikasi (honorification), nonkoreferensi subjek (subject noncoreference), dan peluncuran penjangka kambang (launching float quantifier). Akan tetapi, pengetesan subjek tersebut tidak seluruhnya dapat diaplikasikan untuk mengetes subjek atau kesubjekan. Sehubungan dengan hal itu, Budiarta (2017: 164) menegaskan bahwa subjek merupakan relasi gramatikal sehingga penentuan subjek itu sendiri hendaknya didasarkan pada perilaku gramatikal. Oleh karena ini, penelitian ini mengetes perilaku subjek bahasa Tetum dialek Foho dari segi perspektif tipologi. Artinya, penelitian ini mencoba untuk mencermati dan menelaah data kebahasaan dan ketatabahasaan untuk dapat me-rumuskan dan membuat simpulan tentang pengetesan sifat perilaku subjek bahasa Tetum dialek Foho. Untuk mendapatkan hasil penelitian yang berterima dan pelaksanaan penelitian mungkin dilakukan, masalah penelitian ini dibatasi pada aspek pengetesan sifat perilaku subjek atau kesubjekan bahasa Tetum dialek Foho. Tujuan penelitian ini meliputi tujuan umum, yaitu tujuan sebuah penelitian bahasa yang dilihat dari sudut dimensi teori dan tujuan khusus, yaitu sebuah penelitian bahasa meliputi bahasa sebagai objek penelitian itu sendiri. Artinya, tujuan umum berupaya untuk menggali, menganalisis, dan menjelaskan fenomena pelesapan subjek bahasa dan tujuan khusus berupaya untuk menemukan dan menjelaskan berbagai tes pelesapan subjek bahasa Tetum dialek Foho/Terik. Manfaat penelitian terdiri atas manfaat teoretis dan praktis. Manfaat teoretis memberikan kontribusi bagi pengembangan teori linguistik yang diharapkan dapat bermanfaat sebagai informasi dan acuan dalam usaha untuk memeroleh pengetahu-an dan pemahaman yang berhubungan dengan tipologi sintaksis khususnya dan linguistik umumnya. Manfaat praktis dapat memberikan manfaat untuk merangsang para penutur bahasa Tetum dialek Foho/Terik mempertahankan dan mengembangkan bahasa ibunya sebagai pengungkap jati diri. Selain itu, hasil penelitian ini menjadi wadah dokumentasi sehingga bahasa Tetum dialek Foho/Terik dapat tetap dilestarikan, dijaga keberadaannya, dan mampu hidup sejajar dengan bahasabahasa daerah lainnya. 
Bahasa Tetum yang dikaji para linguis selama ini merupakan salah satu langkah penting untuk pengembangan dan pemertahanan bahasa Tetum itu sendiri. Kajian bahasa Tetum yang dilakukan oleh Suciati (2000) dalam Sukerti (2013: 40) menunjukkan bahwa bahasa Tetum dialek Fehan cenderung bertipe akusatif karena argumen agen (A) pada verba transitif dimarkahi sama dengan satusatunya argumen (S) pada verba intransitif. Argumen inti dalam bahasa Tetum dialek Fehan tidak dimarkahi dengan pemarkah tertentu, yaitu dengan preposisi. Di samping itu, diungkapkan juga dua kelompok verba bahasa Tetum dialek Fehan, yaitu kelompok verba yang bersesuaian dengan subjek dan yang tidak bersesuaian dengan subjek. Bahasa Tetum dialek Fehan dikategorikan bertata urutan kanonis yang tidak bermarkah dengan urutan agen, verba, pasien dengan alternasi pasien, dan agen verba dalam struktur yang bermarkah.

Nama bilangan pokok bahasa Tetum oleh etnik Terum di Provinsi Nusa Tenggara Timur telah disenaraikan Sanga (2017: 11), yaitu ida 'satu', rua 'dua', tolu 'tiga', haat 'empat', lima 'lima', nem 'enam', hitu 'itu'. May (2017: 16) menyatakan bahwa kata benda bahasa Tetum yang dapat dihitung tidak ada penambahan fonem $/ \mathrm{s} /$. Bahasa Tetum Terik (Tetum Fehan atau Tetum Laos) digunakan olen sebagian penduduk di daerah Provinsi Timor Timur. Penutur bahasa dialek Tetum Terik yang berjumlah sekitar 400.000 orang mendiami wilayah Kabupaten Vikeke, Kovalima, dan di sebagian wilayah Kabupaten Manatuto. Bahasa Tetum dialek Terik digunakan juga di Kabupaten Belu, di Provinsi Nusa Tenggara Timur, di Wilayah Timor yang berbatasan dengan Provinsi Timor Timur (Fernandez (2017: 31). Selanjutnya, dirumuskan bahwa konstruksi posesif bahasa Tetum, Lamaholot, dan Mai Brat, baik dalam pola urutan menerangkan-diterangkan maupun diterangkan-menerangkan mirip (Fernandez, 2017: 36). Renoat (2017: xvi) merumuskan bahwa bahasa Tetum memikili gugus konsonan $/ \mathrm{kw} /$, /ks/, dan /k1/. Secara leksikon bahasa Tetum, Dawan, dan Rote berkategori bahasa non-vokalis dengan frekuensi terbanyak, yaitu dua suku kata. Dalam kajian diakronis, dengan teknik leksikostatistik hubungan kekerabatan ketiga bahasa dikategorikan dalam kelompok keluarga bahasa.

Kajian properti subjek bahasa Tetum dialek Foho ini tentu dapat direalisaikan dengan dukungan berapa konsep linguistik, yaitu argumen, fungsi gramati, klausa, relasi gramatikal, subjek, dan tipologi bahasa.

Argumen adalah unsur sintaksis yang diperlukan oleh verba (Matthews, 1997: 2425 dalam Yadnya, 2017: 4-5). Argumen diwujukan melalui hubungan gramatikal berupa S(ubjek), O(bjek), $\mathrm{P}$ (Predikat), OL (objek langsung), dan OTL (objek tidak langsung) atau melalui peran semantik berupa: agent (A), patient (P), dan lain-lain (Trask, 1993:20). Pembahasan tentang fungsi gramatikal tidak bisa terlepas dan mutlak menyangkut predikat yang ditempati verba dari sebuah klausa karena bagaimanapun juga penetapan dan pemahaman tentang agen dan pasien ini diisyaratkan oleh verba (predikat) Budiarta (2013: 243). Kridalaksana (1993: 110) menjelaskan bahwa klausa merupakan satuan gramatikal yang berwujud kelompok kata yang sekurang-kurangnya terdiri atas subjek dan predikat dan memiliki potensi untuk menjadi kalimat. Bahasan relasi gramatikal menurut Comrie (1983: 59) dan Blake (1981: 1) dalam Budiarta (2013: 246) adalah bagian-bagian atau unsur-unsur klausa/kalimat yang dikategorikan sebagai subjek (S), objek langsung (OL), dan objek tak langsung (OTL). Ketiga relasi gramatikal tersebut bersifat sintaktis. Kridalaksana (1993: 204) berpendapat bahwa subjek merupakan bagian dari sebuah klausa/kalimat yang berwujud nomina atau frasa nominal yang menandai apa yang dikatakan oleh pembicara. Konsep subjek sering disalahartikan dengan fungsi-fungsi yang bersifat semantis dan pragmatis. Sesungguhnya, subjek merupakan aspek sintaksis. Subjek dalam setiap klausa atau kalimat memiliki peranan yang sangat penting untuk menjadikan klausa/kalimat lebih utuh atau sempurna (Palmer, 1994: 2). Kridalaksana (2013:85) menyatakan bahwa tipologi bahasa merupakan pengelompokan 
bahasa berdasarkan ciri-ciri fonologis, gramatikal atau leksikal untuk menemukan tipe-tipenya, lepas dari perkembangan historisnya.

Penelitian ini mengaplikasikan teori tipologi bahasa yang dikembangkan oleh Comrie pada awal tahun 1980-an. Beliau mengembangkan kajian linguistik lintas bahasa yang mengarah kepada generalisasi dan pengelompokan bahasa-bahasa. Kajian linguistik yang dikembangkan oleh Comrie ini berada pada tataran morfosintaksis yang membahas (1) pemarkahan agen dan pasien, (2) urutan kata, (3) koordinasi, dan (4) subordinasi (Mallinson dan Blake, 1981: 12). Pengelompokan berdasarkan struktur ini tidak berarti bahwa bahasa-bahasa dikelompokkan hanya berdasarkan struktur, tetapi juga dapat dibedakan berdasarkan genetis, tipologis, dan areal (Mallinson dan Blake, 1981: 4--5). Sehubungan dengan itu, untuk dapat sampai pada penentuan tipologi bahasa, banyak aspek kebahasaan yang perlu dikaji lebih dahulu, baik secara gramatikal (morfosintaksis) maupun melibatkan fenomena semantis. Selain itu, pada dasarnya kajian tipologi bahasa terkait dengan pengelompokan bahasa-bahasa menurut strukturnya (Budiarta, 2013: 41). Sementara itu, kajian yang berusaha mencermati fiturfitur dan ciri khas gramatikal bahasa-bahasa di dunia yang kemudian membuat pengelompokan yang bersesuaian dengan parameter tertentu merupakan kajian tipologi linguistik (linguistic typology). Hasil kajian seperti itu melahirkan tipologi bahasa; yaitu pengelompokan bahasa dengan sebutan kelompok tertentu berdasarkan kecenderungan kesamaan sifat-perilaku gramatikalnya (Jufrizal, 2017: 232).

\section{Metode Penelitian}

Penelitian ini menggunakan ancangan penelitian deskriptif yang bersifat kualitatif yang bertujuan menggambarkan data bahasa secara alamiah. Lokasi penelitian ini adalah di Desa Nanaet Dubessi, Kecamatan Taseteto Barat, Kabupaten Belu, Provinsi Nusa Tenggara Timur pada bulan Agustus 2017. Objek penelitian ini adalah properti subjek bahasa Tetum dialek Foho di Desa Nanaet Dubessi, Kabupaten Belu, Provinsi Nusa Tenggara Timur. Sumber data penelitian berupa data primer berupa tuturan klausa atau kalimat bahasa Tetum dialek Foho. Informan penelitian ini merupakan penutur asli bahasa yang diteliti yang berdomisili di Desa Nanaet Dubessi, Kecamatan Taseteto Barat, Kabupaten Belu, Provinsi Nusa Tenggara Timur dipengaruhi oleh kualifikasi dan kemampuan penutur itu untuk menguasai bahasanya. Instrumen utama penelitian ini adalah peneliti sendiri karena peneliti yang secara langsung ke lapangan. Pengumpulan data menggunakan metode linguistik lapangan yang meliputi, yaitu (1) elisitasi langsung, (2) metode perekaman, dan (3) metode pengecekan elisitasi (Mithun, 2001: 34--43). Teknik pemerolehan data menggunakan metode simak dengan menyimak penggunaan bahasa lisan oleh informan dan metode cakap berupa percakapan peneliti dengan informan dalam mengumpulkan data penelitian. Berkaitan dengan metode dan teknik analisis data, data yang diperoleh dalam proses pengumpulan data melalui hasil teknik elisitasi diseleksi dan diklasifikasikan secara sistematis berdasarkan kelompok permasalahan yang dibahas. Setelah data terkumpul, langkah selanjutnya adalah proses analisis data. Dalam proses analisis data, metode yang digunakan adalah metode agih (metode distribusional). Metode agih merupakan metode analisis yang menjadikan bagian dari bahasa yang diteliti sebagai alat penentu analisis (Djajasudarma, 1993a: 60; Sudaryanto, 1993: 31--100).

\section{Hasil dan Pembahasan}

Fungsi gramatikal subjek berdasarkan konsepsi tata bahasa leksikal-fungsional merupakan fungsi gramatikal tertinggi di dalam hierarki fungsi gramatikal memiliki sejumlah alat tes (Falk, 2001: 58). Subjek merupakan fungsi gramatikal paling utama yang biasanya ditempati oleh nomina atau frasa nominal dalam sebuah kalimat. Subjek bersifat sintaksis sehingga untuk pengetesannya harus didahului secara sintaksis pula dan bukan secara semantis (Artawa, 1998 dalam Budiarta 2013: 250). Secara lintas 
bahasa, properti subjek bervariasi antara satu bahasa dan bahasa lain. Meskipun demikian, terdapat kesamaan properti subjek, misalnya argumen verba transitif yang berperilaku sama dengan argumen intransitif. subjek merupakan relasi gramatikal sehingga penentuan subjek itu sendiri hendaknya didasarkan pada perilaku gramatikal. Dalrymple (2001: 17--19) dalam Budiarta (2013: 250) mengungkapkan bahwa terdapat beberapa alat uji untuk menentukan subjek atau kesubjekan, seperti persesuaian (agreement), honorifikasi (honorification), nonkoreferensi subjek (subject noncoreference), dan peluncuran penjangka kambang (launching float quantifier). Keempat sifat-perilaku subjek yang dikemukakan tersebut tidak seluruhnya dapat digunakan untuk melakukan pengujian subjek atau kesubjekan setiap bahasa. Dengan mengacu pada sifat-perilaku subjek yang dikemukakan Budiarta (2013:250--250), perilaku subjek bahasa Tetum dialek Foho dapat dites melalui (1) struktur kanonis, (2) penyisipan adverbial, (3) perelatifan, penjangka kambang, (5) perefleksifan, penaikan (raising), dan (7) pemfokusan.

\subsection{Struktur Kanonis}

Subjek bahasa Tetum dialek Foho muncul pada posisi praverbal pada struktur kanonis (tata urutan kata) sehinnga klausa bahasa itu dapat dinyatakan berpola kanonis SVO (agen verba - pasien), yaitu subjek muncul di sebelah kiri predikat (Budiarta 2017: 164). Argumen inti yang mengisi posisi subjek dalam struktur kanonikal menempati posisi praverbal (posisi kiri verba) pada klausa intransitif dapat dilihat pada contoh berikut.
(1) Emi hemu we.
$\mathrm{S} \quad \mathrm{P} \quad \mathrm{O}$
3Jm minum air'.
'Mereka minum air'.
(2)

$\begin{array}{lll}\text { Ama } & \text { ba ne toos } \\ \mathrm{S} & \mathrm{P} & \text { Ket } \\ \mathrm{PPs} & \text { pergi ke } & \text { kebun. } \\ \text { 'Ayah } & \text { pergi ke } & \text { kebun'. } \\ \text { Emi } & \text { mai } & \text { nosi Atambua } \\ \mathrm{S} & \mathrm{P} & \text { Ket } \\ \text { 3Jm } & \text { datang } & \text { dari kebun. } \\ \text { 'Mereka datang } & \text { dari Atambua }\end{array}$

Klausa bahasa Tetum dialek Foho (1--3) merupakan klausa intransitif. Klausa tersebut memiliki satu argumen inti yang menempati posisi praverbal atau berada di sebelah kiri predikat. Agumen inti emi 'mereka' pada klausa (1) terletak di sebelah kiri predikat verba (sebelum verba/praverbal) hemu 'minum'. Agumen inti ama 'ayah pada klausa (2) terletak di sebelah kiri predikat verba (praverbal) ba 'pergi'. Agumen inti 'mereka' sebagai argumen inti pada klausa (3) terletak di sebelah kiri predikat verba (praverbal) mai 'datang'. Kelima argumen inti pada klausa (1-3) yang terletak di sebelah kiri predikat secara sintaksis merupakan subjek gramatikal yang berposisi di awal klausa. Struktur kanonis pada klausa intransitif bahasa Tetum dialek Foho pada klausa (1-3) hanya menghadirkan subjek pada posisi praverbal (sebelum verba). Selain predikat yang ditempati verbal, predikat klausa intransitif bahasa Tetum dialek Foho juga dapat ditempati oleh predikat nonverbal. Klausa intransitif dengan predikat nonverbal dapat dilihat pada contoh di bawah ini.

$\begin{array}{ll}\text { Maunniak } & \text { guru. } \\ \mathrm{S} & \mathrm{P} \\ \text { abangnya } & \text { guru. } \\ \text { 'Abangnya guru } \\ \text { Ama rekas. } \\ \mathrm{S} & \mathrm{P} \\ \text { ayah kurus. } \\ \text { 'Ayah kurus'. } \\ \text { Oan emak lima } \\ \mathrm{S} & \mathrm{P}\end{array}$

Anak mereka lima.

'Anak mereka lima'.

$$
\text { Om iha pasar. }
$$

$\mathrm{S} \quad$ Ket

paman di pasar

'Paman di pasar'.

Klausa (4-7) tergolong klausa intransitif. Klausa tersebut ditempati oleh predikat nonverbal yang terdiri atas satu argumen dan predikat. Argumen inti maunniak 'abangnya pada klausa (4) terletak di sebelah predikat nomina guru 'guru'. Argumen inti maunniak 'abangnya pada klausa (5) terletak di sebelah predikat ajektiva rekas 'kurus'. Argumen inti maunniak 'abangnya pada klausa (6) terletak di sebelah predikat pronomina lima 'lima'. 
Argumen inti om 'paman' pada klausa (7) terletak di sebelah keterangan frasa nominal iha pasar 'di pasar'. Argumen inti dalam klausa intransitif dengan predikat non-verbal pada klausa (4-7) tertelak di sebelah kiri predikat yang secara sintaksis berfungsi sebagai subjek. Jadi, klausa intransitif bahasa Tetum dialek Foho secara struktur kanonik menunjukkan bahwa posisi argumen inti berada di sebelah kiri predikat (praverbal). Berkaitan dengan hal itu, bagaimanakah struktur kanonik pada klausa transitif, baik ekatransitif maupun dwitransitif dalam bahasa Tetum dialek Foho. Hal itu dapat dilihat pada contoh berikut.

(8) Mane nee nadinah veto nee laki-laki def mencium wanita def 'Laki-laki itu mencium wanita itu'.

(9) Ina buik nolabodik nia sondal ibuku membelikan dia sandal 'Ibuku membelikan dia sandal'.

Klausa ekatransitif (8) mengandung dua argumen inti yang secara semantis berperan sebagai aktor dan un-dergoer. Argumen inti mane nee 'laki-laki itu' pada klausa (8) secara semantis berperan sebagai agen, sedangkan argumen inti veto nee 'wanita itu' secara semantis berfungsi sebagai tema (tm). Argumen inti mane nee 'laki-laki itu' yang menduduki posisi sebelum predikat (praverbal) secara sintaksis merupakan subjek. Klausa dwitransitif (9) mengandung tiga argumen inti. Konstruksi Ina buik 'ibuku', nia 'dia', dan sondal 'sandal' tergolong argumen inti. Ketiga argumen inti yang terletak di sebelah kiri predikat praverbal merupakan subjek secara sintaksis. Hal demikian dapat dimaknai bahwa dalam bahasa Tetum dialek Foho dapat dinyatakan bahwa subjek hanya dapat muncul pada posisi sebelah kiri predikat (praverbal), baik predikat verbal maupun predikat nonverbal pada klausa ekatransitif dan dwitransitif.

\subsection{Penyisipan Adverbial}

Adverbial adalah unsur yang paling periferal dalam struktur klausa dan telaah perilaku sintaktisnya dapat dikaitkan dengan subjek (Effendi, 2004: 12). Antara subjek dan verbal dapat disisipi oleh adverbial dan penegasi. Adverbial dapat disisipkan di antara argumen inti yang menempati posisi praverbal dan predikat pada klausa bahasa Tetum dialek Foho dengan berupa pemarkah kala awan 'besok' seperti dicontohkan berikut ini.

(10) Ami vila ba uma

$1 \mathrm{Jm}$ pulang ke rumah

'Kami pulang ke rumah'.

(11) Ita awan vila ba Kupang

$1 \mathrm{Jm}$ besok pulang ke Kupang

'Kita besok pulang ke Kupang'.

Klausa intransitif Ami vila ba uma 'Kami pulang ke rumah' pada (10) mengandung satu argumen inti sebelum praverbal dan predikat mendahului adverbial. Klausa intransitif Ita awan vila ba Kupang 'Kita besok pulang ke Kupang' pada (11) terdapat adverbial di antara argumen inti dan predikat. Argumen inti ami 'kami pada (10) dan ita 'kita' pada (11) merupakan argumen inti yang secara sintaksis berfungsi sebagai subjek. Kesubjekan pada klausa transitif, baik klausa ekatransitif maupun dwitransitif dapat dites melalui contoh berikut.

Emato'o tae ami

3Jm Defr memukul 1Jm

'Mereka itu memukul kami'

Bein nola niakbuku

nenek membelikan 3Tg buku

'Nenek membelikan dia buku'.

(14) Ema ne harsehiktae hau

orang Def Adv memukul saya

'Orang itu kemarin memukul saya'.

Bein kami sesawan nola niak

buku

nenek Adv membelikan 3Tg buku

'Nenek besok pagi membelikan dia buku'.

Klausa Ema to'o tae ami 'Mereka itu memukul kami' pada (12) tergolong klausa ekatransitif yang mengandung dua argumen inti, yaitu ema to'o 'orang itu' dan ami 'kami'. Klausa Bein nola niak buku 'Nenek membelikan dia buku' pada (13) tergolong klausa dwitransitif yang mengandung tiga argumen inti, yaitu ema 'nenek', tae 'dia', dan buku 'buku'. Adverbial harsehik 'kemarin' pada klausa (14) terletak di antara argumen 
inti ema ne 'orang itu' dan predikat tae 'memukul'. Adverbial kami sesawan 'besok pagi' pada (15) terletak di antara argumen inti bein 'nenek' dan predikat nola 'membelikan'. Argumen inti pada (12-15) yang terletak sebelum verba secara sintaksis merupakan subjek.

Pengetesan kesubjekan bahasa Tetum dialek Foho juga dapat dilakukan dengan penegasian seperti pada contoh berikut.

(18) Hau beinoan la ba ne gereja awan cucu saya Neg pergi ke gereja besok 'Cucu saya tidak pergi ke gereja besok'.
Hau la kouk kemu kopi
$1 \mathrm{Tg}$ Neg suka minum kopi
'Saya tidak suka minum kopi'.

Klausa (18) dan (19) tergolong klausa negatif bahasa Tetum dialek Foho. Bentuk negasi la tidak dalam klausa instransitif (18) terletak di antara argumen inti hau beinoan 'cucu saya' dan verba $b a$ 'pergi' dan argumen inti hau 'saya' dan verba kouk 'suka' dalam klausa transtifi (19). Kehadiran penegasi la 'tidak' dalam kedua klausa tersebut berfungsi sebagai subjek secara (gramatikal) sintaksis.

\subsection{Perelatifan}

Sistem perelatifan (relativizing) digunakan untuk merelatifkan nomina atau frasa nomina yang sama yang terdapat dalam salah satu klausa sehingga dua klausa dapat digabungkan menjadi satu klausa luas. Alat perelatif dalam bahasa Indonesia disebut pronomina relatif atau kata ganti relatif dengan bentuk yang. Pronomina relatif dalam bahasa Indonesia disebut juga kata ganti relatif sebagai alat bantu penghubung karena tugasnya sebagai pengganti konstituen atau unsur posisi tertenbtu dalam klausa relatif dan sekaligus menggabungkan dua klausa, yaitu klausa bebas (independent clause)dan klausa terikat (dependent clause) (Quirk dan Greenbaum, 1985: 378 dalam Dalilan dan Malyono, 2017: 425). Bahasa Indonesia dapat merelatifkan subjek secara langsung (Dalilan dan Malyono, 2017: 433 - 434) seperti pada contoh berikut ini.
(20) Emi
nee tur iha kursi.
3Jm Def duduk di kursi

'Mereka duduk di kursi'.

(21) Vetone nee alin hauk.

perempuan Def adik saya

'Perempuan itu adik saya'.

(22) Ema mak rekas too narik iha uma oin.

orang Ref kurus itu berdiri di rumah halaman

'Orang yang kurus itu berdiri di halaman rumah'.

(23) Mane maktei

bola too maun hauk

laki-laki Ref menendang bola itu kakak saya

'Laki-laki yang menendang bola itu kakak saya'.

Argumen inti di awal klausa intransitif bahasa Tetum dialek Foho atau di sebelah kiri predikat pada $(20-23)$ semuanya dapat direlatifkan. Posisi nomina berupa orang ketiga jamak emi 'mereka' pada (20) adalah di sebelah kiri predikat tur 'duduk' yang secara semantis berfungsi sebagai agen. Posisi frasa nominal vetone nee 'perempuan itu' pada (21) adalah di sebelah kiri predikat nonverbal (nominal) alin hauk 'adik saya'. Klausa (20) dan (21) dapat direlatifkan menjadi (22) dan (23). Argumen inti sebagai subjek gramatikal yang secara semantis berfungsi sebagai agen pasien pada posisi awal atau sebelum predikat pada (20) dan (21) dapat direlatifkan dengan permarkah relatif mak 'yang' seperti pada (22) dan (23). Wujud konstruksi subjek yang direlatifkan itu adalah Ema mak 'orang yang' dalam Ema mak rekas too narik iha uma oin 'Orang yang kurus itu berdiri di halaman rumah' pada (22) dan mane mak 'laki-laki yang' dalam 'Laki-laki yang menendang bola itu kakak saya' pada (23).

Selain klausa transitif (20) dan (21) yang dapat mengalami perelatifan seperti pada (22) dan (23), contoh (24-27) berikut ini termasuk juga konstruksi klausa transitif yang mengalami perelatifan.

(24) Mane nee nadinan veto nee pria Def mencium wanita Def 'Pria itu mencium wanita itu'.

(25) Veto nee vo ema nee buku 
perempuan Def membelikan anak Def buku

'Perempuan itu membelikan anak itu buku'.

(26) Vet ne ne diak nee nadinan warik ona nee.

wanita Rel cantik Def mencium bayi Def

'Wanita yang cantik itu mencium bayi itu'.

(27) Ema ne tur nee voo nia

buku nee

orang Rel duduk Def membelikan dia buku Def

'Orang yang duduk itu membelikan dia buku itu'.

Klausa Mane nee nadinan veto nee 'Pria itu mencium wanita itu' pada (24) mengandunga dua argumen inti, yaitu mane nee 'pria itu' dan veto ne 'wanita itu', sedangkan klauwa Veto nee vo ema nee buku 'Perempuan itu membelikan anak itu buku' pada (25) mengandung tiga argumen inti, yaitu Veto nee 'perempuan itu', ema 'anak', dan buku 'buku'.

Argumen inti mane nee 'pria itu' pada (24) dan veto nee 'perempuan itu'pada (25) berfungsi sebagai subjek secara sintaksis. Keduanya berposisi di awal atau sebelum predikat nadinan 'mencium' pada (25) dan vo 'membelikan' yang dapat direlatifkan seperti pada (26) dan (27). Hal itu berarti bahwa argumen yang menempati posisi sebelum predikat dan dapat mengalami perelatifn berarti argumen itu dikategorikan subjek.

\subsection{Penjangka Kambang}

Salah satu di antara pengetesan subjek adalah penjangka kambang (quantifier float) (Dalrymple, 2001: 17). Disebut penjangka kambang karena dapat menduduki lebih dari satu posisi di dalam kalimat, tanpa mengubah makna (Purwo, 1989:469 -470) dalam Kosmas (2017:2). Penjangka atau yang lebih dikenal dengan istilah kata bantu bilangan (quantifier) tak takrif merupakan penentu penunjuk jumlah. Sehubungan dengan pengetesan subjek, penjangka kambang dapat menentukan apakah sebuah frasa nomina dapat dikategorikan sebagai subjek atau tidak dengan strategi pengambangan penjangka. Apabila pengambangan penjangka tetap mengacu pada frasa nomina yang sama, terutama yang diasumsikan sebagai subjek, frasa nomina itu adalah subjek. Sebaliknya, kalau pengambangan penjangka tersebut tidak mengacu pada frasa nomina subjek, frasa nomina tersebut bukan subjek. Oleh karena itu, penjangka kambang bahasa Tetum dialek Foho yang berfungsi untuk menunjukkan jumlah kolektif adalah horu 'semua'. Penjangka kambang dapat menentukan apakah sebuah frasa nomina dapat dikategorikan sebagai pengetes subjek atau tidak. Apabila penjangka kambang tersebut tetap mengacu pada frasa nomina yang sama, frasa nomina tersebut adalah subjek. Sebaliknya, jika penjangka kambang tidak mengacu kepada frasa nomina yang berfungsi sebagai subjek frasa nomina tersebut bukan subjek. Contoh pengetesan kesubjekan bahasa Tetum dialek Foho dengan penyangka kambang disajikan dalam konstruksi klausa yang menempatkan penjangka tomak 'semua' setelah subjek.

(28) Ema desa nee/too tomak ba iha kantor desa

penduduk desa itu semua pergi

ke kantor desa

'Penduduk desa itu semua pergi ke kantor desa'.

(29) Emi tomak vaan batar ida minggu isinida

mereka semua menjual jagung satu minggu sekali

'Mereka semua menjual jagung satu minggu sekali'.

Posisi penjangka kambang tomak 'semua' pada (28) adalah di antara argumen inti ema desa nee/too 'penduduk desa itu' dan predikat pada klausa intransitif $b a$ 'pergi'. Posisi penjangka kambang tomak 'semua' pada (29) adalah di antara argumen inti emi 'mereka' dan predikat pada klausa intransitif vaan 'menjual'. Penjangka kambang tomak 'semua' itu menempati posisi setelah nomina atau frasa nomina klausa intransitif yang merupakan subjek gramatikal. 


\subsection{Perefleksifan}

Artawa (1998: 18) dalam Budiarta (2013: 206) menyatakan bahwa agen menjadi pengontrol perefleksifan merupakan kebenaran umum. Agen atau pelaku merupakan bagian yang berfungsi sebagai pengontrol frasa nomina refleksif. Bentuk refleksif bahasa Tetum dialek Foho diungkapkan dengan bentuk vaan 'diri' dan juga dapat ditambahkan dengan kata batar 'sendiri' yang berfungsi untuk mempertegas bentuk refleksif bahasa Tetum dialek Foho. Penggunaan bentuk vaan batar 'diri sendiri' pada klausa refleksif bahasa Tetum dialek Foho disajikan pada contoh berikut

(30) Emi tomak vaan batar

1Tg memukul diri sendiri

'Saya memukul diri sendiri'.

Hau tae vaan batar

3Tg menampar diri sendiri

'Dia menampar diri sendiri'.

Nia basa nikar nia vaan batar

3Jm melihat diri sendiri

'Mereka melihat diri sendiri'.

Agen pada klausa relatif (30) adalah agen emi 'saya'), pada (31) hau 'dia', dan pada (32) nia 'mereka'. Ketiga agen tersebut merupakan subjek gramatikal. Bentuk refleksif yang diungkapkan dengan kata vaan batar 'diri sendiri' dikontrol oleh agen. Jadi, agen bahasa Tetum dialek Foho dapat berfungsi untuk mengontrol perefleksifan.

\subsection{Penaikan (raising)}

Budiarta (2013:270) menyatakan bahwa kaidah penaikan (raising) mempunyai pengertian bahwa sebuah kategori gramatikal (sintaksis) yang sebelumnya bukan merupakan subjek melalui mekanisme tertentu dapat dinaikkan fungsinya menjadi subjek. Fungsi gramatikal yang dapat dinaikkan menjadi subjek dalam bahasa Tetum dialek Foho adalah fungsi gramatikal objek melalui mekanisme pemasifan. Karena tidak memiliki afiks yang dilekatkan pada verba untuk membentuk konstruksi pasif, pemasifan bahasa Tetum dialek Foho menggunakan pemarkah hetan 'dapat'. Contoh proses penaikan argumen yang bukan subjek menjadi subjek adalah sebagai betikut.
(32) a. Emi tei manenurak to'o/ne'e

$3 \mathrm{Jm}$ menendang pemuda Def

'Mereka menendang pemuda itu'.

b. Manenurak to'o hetan nare

ba/nosi emi.

3Jm Def dapat tendang oleh mereka

'Pemuda itu ditendang oleh mereka'.

a. Ina vo alinvarain

ibu membelikan adik celana

'Ibu membelikan adik celana'.

b. Varain hela ba/nosi ina bodik alin celana dibeli oleh ibu untuk adik 'Celana dibeli oleh ibu untuk adik'.

c. Alin vo varain ba/nosi ina adik dibelikan celana oleh ibu

'Adik dibelikan celana oleh ibu'.

Argumen subjek emi 'mereka' dan argumen objek langsung manenurak to'o 'pemuda itu dapat membangun klausa ekatransitif (32a). Klausa (32b) menunjukkan bahwa proses penaikan argumen objek langsung manenurak to'o 'pemuda itu' dapat dilakukan untuk menempati posisi subjek. Klausa (33a) merupakan klausa dwitransitif yang dibangun oleh argumen ina 'ibu' yang berfungsi sebagai subjek, argumen ali 'adik' yang berfungsi sebagai objek tak langsung, dan argumen varain 'celana' yang berfungsi sebagai objek langsung. Klausa (33b) merupakan hasil dari proses penaikan argumen objek langsung varain 'baju' pada klausa (33a) menjadi argumen yang secara gramatikal berfungsi sebagai subjek. Klausa (33b) juga menunjukkan bahwa argumen objek langsung dapat dinaikkan menjadi subjek gramatikal. Sementara, klausa (33c) menunjukkan bahwa argumen objek tak langsung dapat dinaikkan menjadi subjek gramatikal. Jadi, penaikan juga dapat digunakan untuk menentukan subjek atau kesubjekan bahasa Tetum dialek Foho.

\subsection{Pemfokusan}

Chaer (2007: 263) menyatakan bahwa fokus adalah unsur yang menonjolkan bagian klausa sehingga perhatian pendengar atau pembaca tertuju pada bagian itu. Salah satu penonjolan (pemfokusan/subjek dapat difokuskan) bagian klausa yang dianggap mengandung informasi paling penting sehingga bagian klausa itu 
menjadi pusat perhatian pembaca atau pendengar adalah subjek. Subjek yang berada pada tataran sintaksis klausa dapat dites melalui pemfokusan, yaitu dengan pemarkah ne 'yang'. Subjek klausa intransitif dan transitif yang mengalami pemfokusan dengan pemarkah fokus ne 'yang' berfungsi sebagai subjek karena hanya argumen yang muncul sebelum predikat yang mengalami pemfokusan. Contohnya adalah sebagai berikut.

(34) Veta diakban to'o nananu ne iha gereja.

gadis cantik Def bernyanyi FOK Prep gereja

'Gadis cantik itu bernyanyi dia gereja'.

(35) Emine tae warikoan to'o/ne'e.

3Jm Fok memukul anak itu

'Mereka memukul anak itu'.

(36)

Om ne vo

hau sepatu iha

pasar.

paman Fok membelikan 1Tg sepatu Prep pasar

'Paman membelikan saya sepatu di pasar'.

Klausa intransitif (34) merupakan klausa pemfokusan dan argument veta diakban 'wanita cantik' dalam klausa itu berposisi sebelum predikat nananu 'bernyanyi' yang diikuti oleh pemarkah fokus ne 'yang'.

Argumen klausa ekatransitif emi 'mereka' pada klausa (35) yang menempati posisi sebelum predikat juga langsung diikuti oleh pemarkah fokus ne'yang'. Argumen om 'paman pada klausa dwitransitif (36)berposisi sebelum predikat vo 'membelikan' yang langsung diikuti oleh pemarkah fokus te yang. Klausa (34--36) menunjukkan bahwa argumen pada setiap klausa diikuti oleh pemarkah fokus ne 'yang'. Pemarkah fokus ne 'yang' secara langsung mengikuti dan memarkahi argumen yang menempati posisi sebelum predikat yang ditempati oleh verba. Jadi, pemfokusan merupakan salah satu cara yang dapat digunakan untuk menentukan subjek bahasa Tetum dialek Foho.

\section{Simpulan dan Saran}

\subsection{Simpulan}

Berdasarkan penjelasan sebelum-nya, hasil kajian properti subjek bahasa Tetum dialek Foho di Desa Nanaet Dubessi, Kabupaten Belu, Provinsi Nusa Tenggara Timur dapat disimpulkan, yaitu (1) struktur kanonis muncul pada posisi praverbal, (2) adverbia dan penegasi di antara subjek sebagai argumen praverbal dengan predikat, (3) subjek dapat direlatifkan (perelatifan subjek), (4) penjangka kambang dapat disisipkan di antara subjek dan predikat, (5) subje dapat direfleksifkan (perefleksian), (6) subjek dapat dinaikkan objek langsung dan objek tak langsung (argumen yang bukan subjek) melalui mekanisme penaikan (raising), dan (7) subjek dapat difokuskan dengan kehadiran pemarkah fokus $n e$ 'yang'.

\subsection{Saran}

Aspek lain yang berkaitan dengan tipologi bahasa Tetum dialek Foho di Desa Nanaet Dubessi, Kabupaten Belu, Provinsi Nusa Tenggara Timur masih perlu dilanjutkan.

\section{Daftar Pustaka}

Budiarta, I Wayan. 2013. "Tipologi Sintaksis Bahasa Kemak". Denpasar: Disertasi Program Pascasarjana, Universitas Udayana.

(Perilaku Subjek dalam Bahasa Kemak Kabupaten Belu Nusa Tenggara Timur". Dalam LITERA, 15(1). [https://journal.uny.ac.id/index.php/litera/article/view/ 9776], diunduh 13 Desember 2017.

Chaer, Abdul. 2007. Linguistik Umum. Edisi Baru. Jakarta: Penerbit Rineka Cipta.

Dalrymple, Mary. 2001. Lexical-Functional Grammar: Syntax and Semantics. San Diego: Academic Press.

Djajasudarma, T. Fatimah. 1993. Metode Linguistik: Ancangan Metode Penelitian dan Kajian. Bandung: Eresco.

Dalihan dan Malyono. 2017. "Klausa Relatif Bahasa Inggris dan Bahasa Indonesia: Analisis Konstrastif Strategi Perelatifan, Fungsi, dan Karakteristik 
Alat Perelatif". [http://ilib.ugm.ac.id/jurnal/detail.php?dataId=2069], diunduh tanggal 13 Desember 2017.

Effendi, S. 2004. Adverbial Cara dan Adverbial Sarana dalam Bahasa Indonesia. Jakarta: Pusat Bahasa Departemen Pendidikan Nasional.

Falk, Yehuda N. 2001. Lexical Functional Grammar. Stanford, California: CSLI.

(3) Fernandez, Inyo Yos. 2017. "Konstruksi Posesif Bahasa-bahasa Austronesia dan Non Austronesia di Kawasan Timur Indonesia: Studi Bandingan Bahasa Tetum (Timor Timur), Lamaholot (Flores Timur), dan Mai Brat (Kepala Burung)". [https://journal.ugm.ac.id/index.php/j urnal-humaniora/article/-view/1877], diunduh tanggal 13 Desember 2017.

Jufrizal, dkk. 2006. "Pentopikalan dalam Bahasa Minangkabau dan Kaitannya dengan Upaya Pembina-an SosialBudaya Masyarakat Minangkabau". Pandang: Fakultas Bahasa Sastra dan Seni, Jurusan Bahasa dan Sastra Inggris, Universitas Negeri Padang.

-------------. 2017. “Tipologi Linguistik: Dasar Kerangka Teori dan Arah Kajiannya". [http://jurnalvivid.fib.unand.ac.id/index.php/lingkul/article/vi ew/69/78], diunduh tanggal 18 Desember 2017.

Kosmas, Jeladu. 2017. "Perilaku Penjangka Kambang dalam Bahasa Rongga". [https://ojs.unud.ac.id/index.php/eol/art icle/view/3529/2560], diunduh tanggal 13 Desember 2017.

Kridalaksana, Harimurti. 1993. Kamus Lingusitik. Jakarta: Penerbit PT Gramedia.

2013. Kamus Linguistik. Jakarta: Gramedia Pustaka Utama.

Mallison, G. Blake, B.J. 1981. Language Tipology: Cross-Linguistics Studies in Syntax. Amsterdam: North Holland Publishing Company.

May, Evangelin De Jesus. 2017. "Kata Benda dalam Bahasa Inggris dan Bahasa
Tetum: Analisis Kontrastif'. Jurnal Elektronik Fakultas Sastra Universitas Sam Ratulangi, 2(1). [ttps://ejournal.unsrat.ac.id/index.php/jefs/article/view/ 7878], diunduh tanggal 13 Desember 2017.

Mithun, Marrianne. 2001. "Who Shapes the Record, the Speaker, and the Linguist". Dalam Newman, Paul and Martha Ratliff, Editors. Linguistics Fieldwork. First Edition. Cambridge: Cambridge University Press.

Palmer, F. R. 1994. Grammatical Roles and Relations. Cambridge: Cambridge University Press.

Renoat, Emi. 2017. "Bahasa Tetum, Dawan, dan Rote Di Nusa Tenggara Timur: Kajian Komparatif dan Budaya". [http://etd.repository.ugm.ac.id/index.p hp?], diunduh tanggal 13 Desember 2017.

Sanga, Felysianus. 2017. "Sistem Bilangan Pokok Tradisional dalam Masyarakat Nusa Tenggara Timur: Sebuah Kajian Etnografis".

[https://ojs.unud.ac.id/index.php/lingui stika/article/view/422], diunduh tanggal 13 Desember 2017.

Sudaryanto. 1993. Metode dan Aneka Teknik Analisis Bahasa. Yogyakarta: Duta Wacana University Press.

Sukerti, Gusti Nyoman Ayu. 2013. "Relasi Gramatikal Bahasa Kodi: Kajian Tipologi Sintaksis". Denpasar: Tesis Program Pascasarjana, Universitas Udayana.

Trask, R.L. 1993. A Dictionary of Grammatical Terms in Linguistics. London and New York: Routledge.

Troebus, dkk. 1987. Struktur Bahasa Terum. Jakarta: Departemen Pendidikan dan Kebudayaan.

Yadnya, Ida Bagus Putra. 2017. "Kesubjekan dalam Bahasa Lamaholot Dialek Nusa Tadon".

[http://floresisland.weebly.com/uploads /4/0/9/7/4097021/kesubjekan-dalambahasa-lamaholot.pdf], diunduh tanggal 14 Desember 2017. 